\title{
Prognostic Significance of Bcl-2, Tumor-Associated Macrophages, and Total Neoplastic and Inflammatory Lymph Node Involvement in Advanced Stage Classical Hodgkin's Lymphoma
}

\author{
Ljubomir R. Jakovic ${ }^{a}$ Biljana S. Mihaljevic ${ }^{a, b}$ Maja D. Perunicic Jovanovic ${ }^{c}$ Andrija D. \\ Bogdanovic $^{\mathrm{a}, \mathrm{b}}$ Bosko M. Andjelic ${ }^{a}$ Vladimir Z. Bumbasirevic ${ }^{d}$ \\ ${ }^{a}$ Clinic for Hematology, Clinical Center of Serbia, ${ }^{b}$ Faculty of Medicine, University of Belgrade, 'Department for Histopathology, Clinical \\ Center of Serbia, Institute of Histology and Embryology, Faculty of Medicine University of Belgrade, Belgrade, Serbia
}

Keywords

Prognostic parameters · Advanced Hodgkin's lymphoma

\section{Summary}

Background: Although Hodgkin's lymphoma $(\mathrm{HL})$ is a curable cancer, current treatment strategies based on risk stratification and response modulation are not precise enough. The predictive power of biological and morphological parameters is controversial, with prognostic models not reaching wide acceptance. Patients and Methods: We analyzed the prognostic relevance of 8 parameters in 85 advancedstage classical HL patients, in order to determine whether tissue-based variables could add prognostic value to standard clinical parameters, thus contributing to better risk stratification at presentation. Results: Univariate analysis confirmed 5 indicators of shorter overall survival (OS): Bcl-2 overexpression; increased CD68+ tumor-associated macrophages (TAM); international prognostic score (IPS) > 2; bulky disease; and total lymph node involvement (TLNI) with regard to neoplastic and inflammatory cells. Apart from TLNI, these parameters influenced lower event-free survival (EFS). Multivariate analysis identified 5 independent factors for OS: Bcl-2 overexpression; increased CD68+ TAM; TLNI; IPS > 2; and bulky disease. Increased CD68+ TAM, IPS > 2, and bulky disease affected the EFS. Utilizing the cumulative score of unfavorable prognostic factors for OS, we designed a prognostic model stratifying patients into 4 risk groups (with $0-1,2,3$, or $4-5$ factors), each with progressively reduced OS $(p<0.001)$. Conclusion: Our findings support the combination of tissue-based variables with clinical parameters at diagnosis, identifying patients who are at higher risk of poor outcome.

\section{KARGER}

Fax +497614520714

Information@Karger.de

www.karger.com (c) 2012 S. Karger GmbH, Freiburs

0378-584X/12/3512-0733\$38.00/0

Accessible online at:

www.karger.com/onk
Schlüsselwörter

Prognostische Parameter · Fortgeschrittener Morbus Hodgkin

\section{Zusammenfassung}

Hintergrund: Zwar ist Morbus Hodgkin heilbar, aktuelle Behandlungsstrategien basierend auf Risikostratifizierung und Modulation des Ansprechens sind jedoch nicht präzise genug. Die Vorhersagekraft biologischer und morphologischer Parameter ist kontrovers, und prognostische Modelle werden nicht allgemein akzeptiert. Patienten und Methoden: Wir haben die prognostische Relevanz von 8 Parametern bei 85 Patienten mit fortgeschrittenem klassischen Morbus Hodgkin analysiert, um herauszufinden, ob gewebebasierte Variablen die Vorhersagekraft standardisierter klinischer Parameter verstärken und somit zu einer besseren Risikostratifizierung vorstellig werdender Patienten beitragen könnten. Ergebnisse: Die Univariatanalyse ergab 5 Indikatoren eines kürzeren Gesamtüberlebens: Bcl-2-Überexpression; erhöhte Anzahl an CD68+-tumorassoziierten Makrophagen (TAM); ein International Prognostic Score (IPS) > 2; Bulky Disease; und Gesamtlymphknotenbefall mit neoplastischen und inflammatorischen Zellen. Mit Ausnahme des Gesamtlymphknotenbefalls beeinflussten diese Parameter ein kürzeres ereignisfreies Überleben. Die Multivariatanalyse konnte 5 unabhängige Faktoren für das Gesamtüberleben identifizieren: Bcl-2-Überexpression, erhöhte Anzahl an CD68+-TAM, Gesamtlymphknotenbefall, IPS > 2 und Bulky Disease. Davon beeinflussten die erhöhte Anzahl an CD68+-TAM, IPS > 2 sowie Bulky Disease das ereignisfreie Überleben. Auf der Basis des kumulativen Scores der ungünstigen Prognosefaktoren für das Gesamtüberleben haben wir ein prognostisches Modell erstellt, welches Patienten in 4 Risikogruppen einteilt (mit 0-1, 2, 3 bzw. 4-5 Faktoren), die jeweils ein progressiv reduziertes Gesamtüberleben indizieren $p<0,001)$. Schlussfolgerung: Unsere Ergebnisse unterstützen die Kombination gewebebasierter Variablen mit klinischen Parametern zum Zeitpunkt der Diagnosestellung, um Patienten zu identifiziren, die ein höheres Risiko für ein schlechtes Outcome haben.

Ljubomir R. Jakovic, M.D.

Clinic for Hematology

Clinical Center of Serbia

2 Koste Todorovic St, 11000 Belgrade, Serbia

ljubajak@yahoo.com 


\section{Introduction}

Modern therapeutic strategies result in remission after the initial treatment in more than $90 \%$ of Hodgkin's lymphoma (HL) patients [1]. However, approximately one third of patients with high-risk prognostic features at presentation die following relapse or progressive disease (PD) [2]. In addition, modern therapy advances in HL are often burdened with treatment-related late side effects such as cardiac failure, infertility, or secondary malignancies [3]. Thus, a more accurate prediction of treatment outcome could help to identify patients who might respond less effectively to standard first-line therapy and those who are likely to benefit from reduced treatment [4]. Since the beginning of HL treatment, the identification of prognostic factors and risk-adapted treatment strategies has been a major issue [5]. The conventional treatment strategy has 2 complementary approaches: i) risk stratification using prognostic models based on adverse clinical parameters such as the International Prognostic Score (IPS) and the Ann Arbor classification; and ii) response modulation in which therapy is adapted according to positron emission tomography-computed tomography (PET-CT) findings following induction therapy [6-8]. However, it is difficult to use only these treatment strategies since neither is accurate enough to provide a truly personalized treatment for the individual patient [1]. The biological aspects of HL have also been explored in an attempt to identify reliable initial tissue-based variables as determinants of clinical outcome [9]. Histological subtype, phenotypic characteristics of Hodgkin and ReedSternberg (HRS) cells, microenvironment cell type composition, and increased levels of plasma cytokines/chemokines involved in lymphoma microenvironment formation were related to prognosis [9-15]. Their predictive value has not yet been powerful enough to be included in therapeutic decision making [16]. The aim of this study was to determine whether molecular and pathomorphological parameters could add prognostic value to standard clinical parameters and contribute to a better risk stratification of HL patients. We investigated the prognostic impact of molecular (Bcl-2, survivin, active caspase 3, Ki-67, CD68), pathomorphological (total neoplastic and inflammatory lymph node involvement, TLNI), and clinical parameters (IPS and bulky disease) in advanced stage classical HL (cHL) patients at the time of the initial diagnosis.

\section{Patients and Methods}

A retrospective study was performed on a group of 85 patients treated during the period of 1997-2005. All patients fulfilled the following criteria: initial diagnosis of $\mathrm{cHL}$ following a lymph node biopsy before any treatment; representative surgically extirpated, formalin-fixed, paraffinembedded diagnostic lymph node specimen available for histological revision and further immunohistochemical studies; available clinical and laboratory data on presentation and follow-up records; negative status for human immunodeficiency virus infection; complete staging corresponding to advanced stage cHL according to the Cotswold revision of the Ann Arbor classification criteria; patients were uniformly treated according to treatment guidelines at the time of diagnosis; all had a minimum followup of 5 years. This study was commenced following approval by the Institutional Ethical Board of the Clinic of Hematology, Clinical Center of Serbia, and Ethical Committee of the Faculty of Medicine, University of Belgrade, Serbia, according to the Helsinki Declaration and Good Clinical Practice policy.

\section{Pathological Aspects and Immunohistochemistry}

Two hematopathologists (MPJ and LJ) independently reviewed and evaluated all slides. In all cases the diagnosis of cHL was confirmed by immunophenotyping, and classified according to the WHO classification of tumors of the hematopoietic and lymphoid tissues [17]. Immunohistochemical staining was performed by application of monoclonal antibodies for Bcl-2 (124, monoclonal; DakoCytomation, Glostrup, Denmark), survivin (polyclonal; LabVision, Fremont, CA, USA), active caspase 3 (y83-77, monoclonal; Novus Biologicals, Littleton, CO, USA), Ki-67 (MIB 1, monoclonal; DakoCytomation), and CD68 (PG-M1; DakoCytomation). A peroxidase-labeled detection system was used (LSAB 2, DakoCytomation or Ultravision LPDetection system, LabVision), and a standard antigen retrieval protocol. The determination of the number and percentage of HRS cells and tumor-associated macrophages (TAM) expressing immunohistochemical parameters was performed using a Leica ${ }^{\circledR}$ DMR microscope (Leica Microsystems GmbH, Wetzlar, Germany) at 10 randomly selected high power fields $(\times 400)$ within $\mathrm{cHL}$ infiltrates. The labeling index of positive tumor cells was determined by the correlation between positive HRS and the total number of evaluated HRS cells. The percentage of CD68-positive (CD68+) TAM was determined by correlating CD68+ TAM to the total number of non-neoplastic cells in the $\mathrm{cHL}$ background. According to previously published data, cutoff values of $50 \%$ for Bcl-2, survivin, and $\mathrm{Ki}-67,5 \%$ for active caspase 3 , and $25 \%$ for CD68+ TAM were used for evaluating immunohistochemical results [11, $13,18,19]$.

\section{Pathomorphologic Evaluation}

The pathomorphologic feature of TLNI by neoplastic and inflammatory cells (total involvement versus focal residual secondary follicles) was analyzed according to the German Hodgkin Study Group criteria [20].

\section{Clinical Parameters}

Medical records were reviewed for additional clinical and laboratory data: age, gender, Ann Arbor stage, presence or absence of systemic symptoms, bulky disease, hemoglobin, white blood count, lymphocyte count, and serum albumin. IPS and bulky disease were calculated according to the established criteria $[6,21]$.

Selected variables were chosen on the basis of their prognostic ability, capacity to represent different aspects of the disease, or interactions.

\section{Treatment}

All patients were treated with the same therapeutic schedule, consisting of 6-8 cycles of the classical ABVD regimen (doxorubicine, bleomycine, vinblastine, dacarbazine) and additional radiation therapy (RT) to sites of tumor involvement. Patients with treatment failure/relapse received salvage chemotherapy with the DHAP regimen (dexamethasone, cisplatinum, Ara-c). Having completed this combined treatment, patients were assessed for complete remission (CR), partial remission (PR), stable disease (SD), and PD. Treatment failure was defined as a failure to achieve CR or PR after the initial therapy, or response (CR/PR) less than 3 months after therapy completion. Relapse was defined as disease reoccurrence if previous $\mathrm{CR}$ was achieved at least 3 months after completing treatment, or if the disease progressed in the case of achieved PR. 
Statistical Methods

The main focus of the study, overall survival (OS), was measured from the start of treatment to the date of the last follow-up (censored patients alive by the time of analysis) or time of death from any cause. As a secondary endpoint, event-free survival (EFS) was evaluated from initiation of treatment to the date of disease progression, relapse, or death from any cause, or if none of these events have occurred, the date of the last follow-up (censored patients). Survival analysis was performed using the Kaplan-Meier method. The statistical significance of differences in EFS and OS between groups of patients was estimated by the log rank test. Multivariate analysis was performed using the Cox proportional hazard model. All tests were two-sided with a threshold of $\mathrm{p}=0.05$. All statistical analyses were performed using the 2007 Statistica ${ }^{\circledR}$ version 8.0 (StatSoft, Inc., Tulsa, OK, USA) licensed statistical analysis software package.

\section{Results}

At presentation, stage IIB (with bulky mediastinal tumor and/ or extranodal disease), III, and IV of the disease was present in $7(8 \%), 44(52 \%)$, and $34(40 \%)$ of the patients, respectively. $70(82 \%)$ patients had B symptoms. 46 (54\%) patients were male, and 21 (25\%) were older than 45 years (mean age $35.43 \pm 13.5$ years; range 16-68 years). 43 (51\%) patients had a high IPS score $(>2)$. At initial diagnosis, bulky disease was confirmed in 34 (40\%) patients. According to histopathological tumor type, $78 \%$ were classified as nodular sclerosis subtype, $14 \%$ mixed cellularity, 5\% lymphocyte-rich cHL, and $3 \%$ lymphocyte depletion (table 1 ). Bcl-2, survivin, active caspase-3, and Ki-67 were expressed in HRS cells of 64

Table 1. Baseline characteristics of the analyzed patients $(n=85)$

\begin{tabular}{lc}
\hline & Patients, $\mathrm{n}(\%)$ \\
\hline Demographic data & \\
Male sex & $46(54)$ \\
Age $>$ 45 years & $21(25)$ \\
Clinical data & \\
Ann Arbor stage & $7(8)$ \\
II & $44(52)$ \\
III & $34(40)$ \\
IV & $70(82)$ \\
B symptoms & $43(51)$ \\
IPS (>2), high risk & $34(40)$ \\
Bulky disease & \\
Histologic subtype cHL & $66(78)$ \\
Nodular sclerosis & $12(14)$ \\
Mixed cellularity & $4(5)$ \\
Lymphocyte-rich & $3(3)$ \\
Lymphocyte-depleted & \\
Pathomorphological features & $31(36)$ \\
Total lymph node involvement & \\
Immunohistochemistry - HRS cells & $26(31)$ \\
Bcl-2+ $>50 \%$ & $29(34)$ \\
Survivin $>50 \%$ & $14(16)$ \\
Active caspase 3+ > 5\% & $38(45)$ \\
Ki67 + 50\% & $33(39)$ \\
CD68+ TAM $>25 \%$ &
\end{tabular}

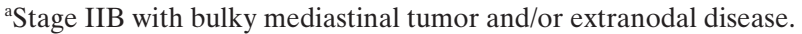
$\mathrm{cHL}=$ Classical Hodgkin s lymphoma; IPS = International Prognostic Score; HRS = Hodgkin and Reed-Sternberg; TAM = tumor-associated macrophages.
(75\%), 77 (91\%), 54 (64\%), and 83 (98\%) cases, respectively. Overexpression (> $50 \% \mathrm{HRS}$ cells) of Bcl-2, survivin, and Ki-67 was detected in $26(31 \%), 29(34 \%)$, and 38 (45\%) of patients, respectively. 14 (16\%) patients had active caspase-3 in more than 5\% HRS cells. Expression of CD68 was detected in all examined cases. 33 (39\%) patients had $>25 \%$ of TAM. TLNI with neoplastic and inflammatory cells was present in $31(36 \%)$ cases at diagnosis (table 1). 57 of the 85 included patients are still alive with a median follow-up of 88 months. $18(21 \%)$ patients were primarily refractory to the treatment and subsequently died. 10 out of 26 patients with relapse had a fatal outcome. 5-year EFS and OS were 61 and $68 \%$, respectively, for the entire study population.

\section{Univariate Analysis}

Univariate analysis showed that the following factors were associated with lower OS: Bcl-2 overexpression by HRS cells $(>50 \%)\left(\mathrm{OS}_{5 \mathrm{yrs}}\right.$ with/without risk factor 50 vs. $80 \%$, respectively; $\log$ rank $\mathrm{p}=0.007)$; increased number $(>25 \%)$ of CD68+ TAM $\left(\mathrm{OS}_{5 \mathrm{yrs}}\right.$ with/without risk factor 52 vs. $83 \%$, respectively; log rank $p=0.003)$; high IPS score $(>2)\left(\mathrm{OS}_{5 y \mathrm{rs}}\right.$ with/without risk factor 51 vs. $90 \%$, respectively; log rank $\mathrm{p}<0.001)$; bulky disease $\left(\mathrm{OS}_{5 \mathrm{yrs}}\right.$ with/without risk factor 53 vs. $82 \%$, respectively; $\log$ rank $\mathrm{p}=0.002)$; and TLNI with neoplastic and inflammatory cells $\left(\mathrm{OS}_{5 \mathrm{yrs}}\right.$ with/without risk factor 55 vs. $80 \%$, respectively; $\log$ rank $\mathrm{p}=0.017$ ) (fig. 1 ). Factors with significant impact on EFS were: Bcl-2 overexpression $\left(\mathrm{EFS}_{5 \mathrm{yrs}}\right.$ with/without risk factor 43 vs. $68 \%$, respectively; log rank $\mathrm{p}=0.031)$; increased number of CD68+ TAM $\left(E_{5 F} S_{\text {yrs }}\right.$ with/without risk factor 48 vs. $68 \%$, respectively; log rank $\mathrm{p}=0.035)$; high IPS score $(>2)\left(\mathrm{EFS}_{5 \mathrm{yrs}}\right.$ with/without risk factor 46 vs. $74 \%$, respectively; log rank $\mathrm{p}=0.004)$; bulky disease $\left(\mathrm{EFS}_{5 \mathrm{yrs}}\right.$ with/without risk factor 44 vs. $71 \%$, respectively, log rank $p=0.014)$ (fig. 1). In addition, TLNI showed a trend towards lower EFS $\left(\mathrm{EFS}_{5 \mathrm{yrs}}\right.$ with/without risk factor 48 vs. $66 \%$, respectively; $\log$ rank $\mathrm{p}=0.087$ ) (fig. 1). The factors survivin, active caspase 3, and Ki-67 showed no significant impact on OS $(\log$ rank $\mathrm{p}=0.065$, $\mathrm{p}=0.787$, and $\mathrm{p}=0.187$, respectively) and EFS (log rank $\mathrm{p}=0.153, \mathrm{p}=0.677$, and $\mathrm{p}=0319$, respectively).

\section{Multivariate Analysis}

The multivariate analysis for OS, including all univariately significant risk factors, identified Bcl-2+>50\%, > 25\% CD68+ TAM, TLNI, IPS $>2$, and bulky disease as independent prognostic factors for OS ( $\mathrm{p}=0.026, \mathrm{p}=0.042, \mathrm{p}=0.004$, $\mathrm{p}=0.0004$, and $\mathrm{p}=0.003$, respectively). In a respective model for EFS, increased CD68+ TAM, IPS $>2$, and bulky disease remained significant $(\mathrm{p}=0.044, \mathrm{p}=0.009$, and $\mathrm{p}=0.018$, respectively) (table 2 ).

\section{Survival Model}

Based on the cumulative score of identified unfavorable prognostic factors for OS (2 molecular, 1 morphological, and 
2 clinical), a prognostic score was developed. The number of patients in each group was as follows: 12 patients had no factors; 16 had 1; 32 had 2; 14 had 2; 10 had 4; and 1 patient had all 5 factors. Intergroup analysis showed no difference in OS between patients having a cumulative score of 0 and 1 $(\mathrm{p}=1.0)$ and those with a score of 4 and $5(\mathrm{p}=0.98)$. On the basis of these results, we propose a survival model that stratifies patients into 4 risk groups according to the number of adverse prognostic factors. Patients with no or 1 prognostic factor are considered low risk, 2 intermediate, 3 high, and 4-5
A
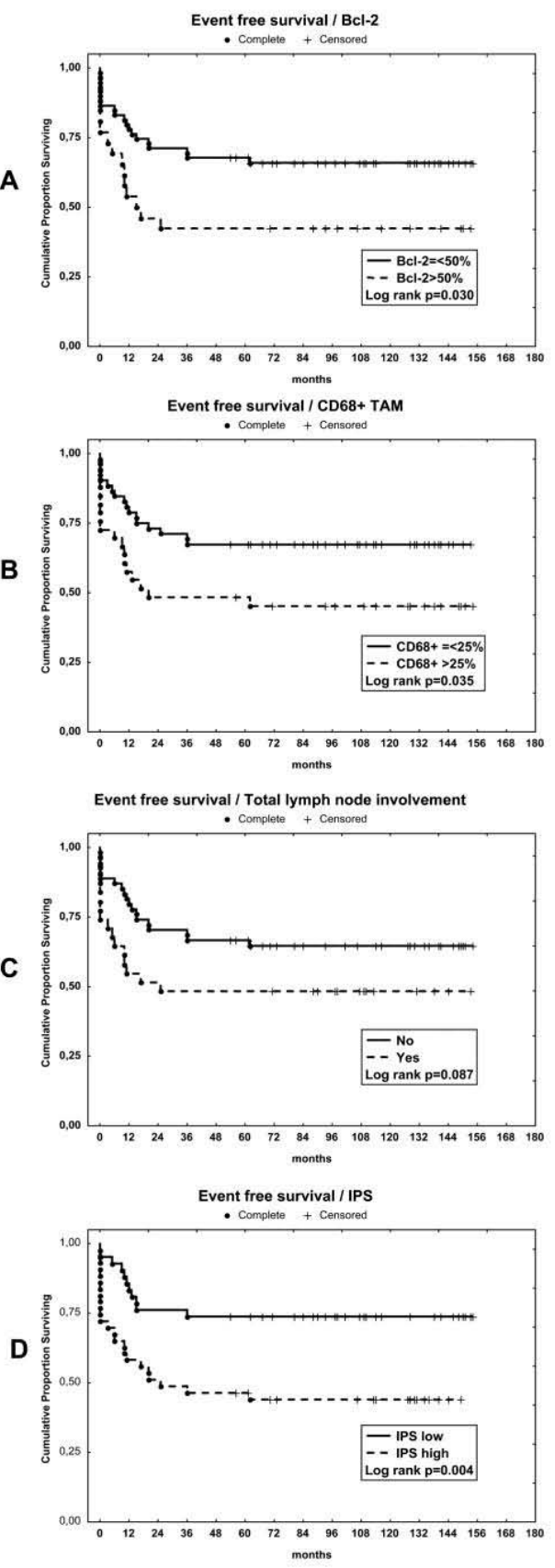

Event free survival / Bulky diseas

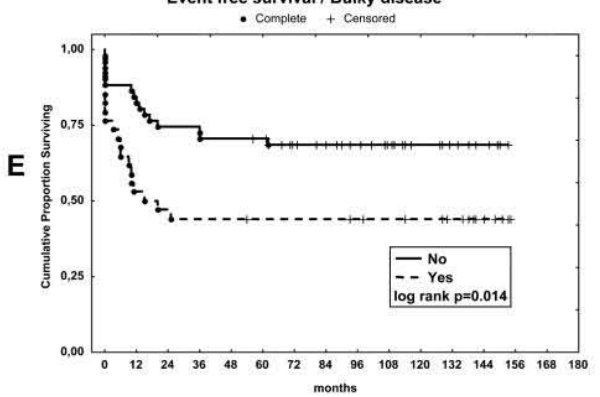

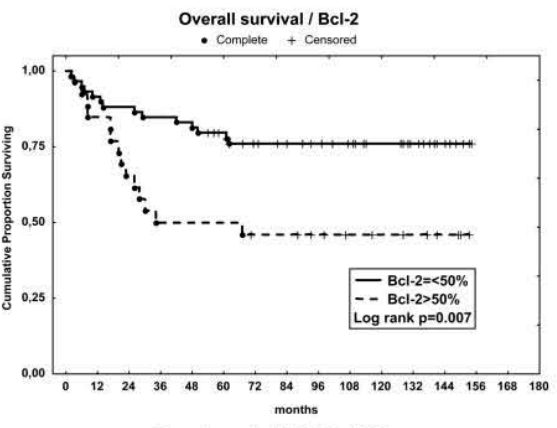
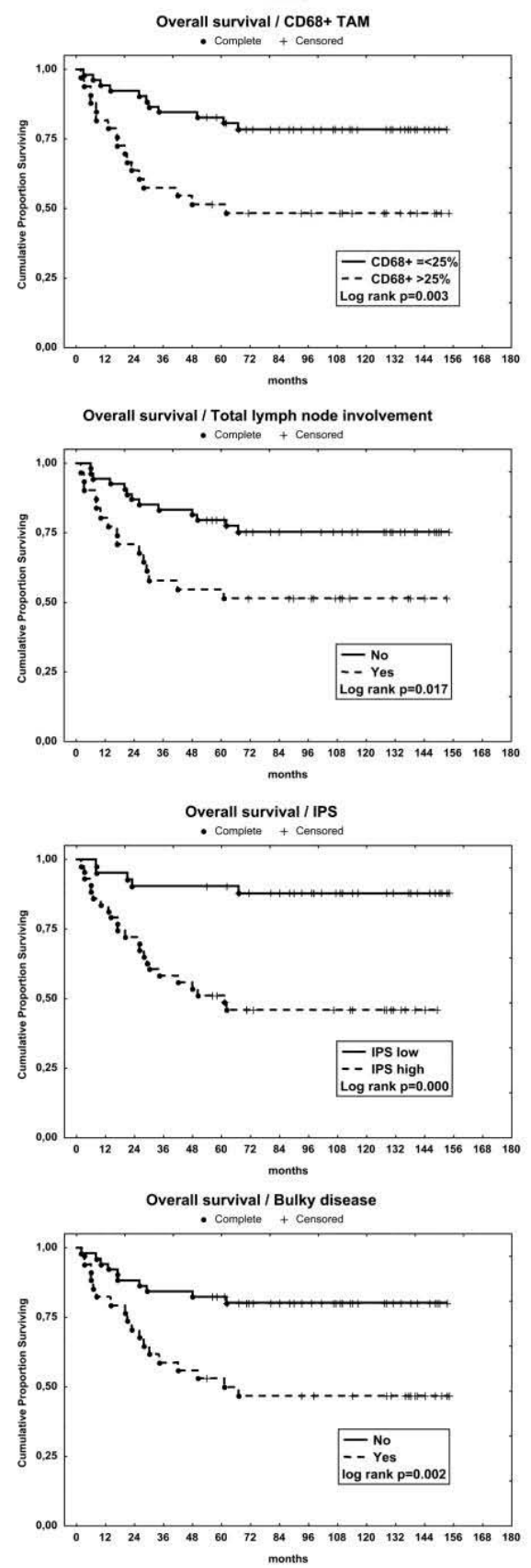

Fig. 1. Event-free survival curves (left) and overall survival curves (right) based on A Bcl-2, B CD68, C total lymph node involvement (TLNI), D International Prognostic Score (IPS), and $\mathbf{E}$ bulky disease. 
Table 2. Multivariate analysis $(\mathrm{n}=85)$

\begin{tabular}{|c|c|c|c|c|c|c|}
\hline \multirow[t]{2}{*}{ Variable } & \multicolumn{3}{|c|}{ Event-free survival } & \multicolumn{3}{|c|}{ Overall survival } \\
\hline & $\mathrm{p}$ value & risk ratio & $\mathrm{CI}$ & $\mathrm{p}$ value & risk ratio & $\mathrm{CI}$ \\
\hline Bcl-2+ HRS > 50\% & 0.117 & 1.747 & $0.869-3.510$ & 0.025 & 2.452 & $1.114-5.395$ \\
\hline $\mathrm{CD} 68+\mathrm{TAM}>25 \%$ & 0.044 & 2.016 & $1.018-3.993$ & 0.003 & 3.243 & $1.468-7.162$ \\
\hline TLNI & 0.147 & 1.667 & $0.835-3.328$ & 0.042 & 2.241 & $1.029-4.883$ \\
\hline IPS $>2$ & 0.009 & 2.598 & $1.262-5.347$ & 0.000 & 6.031 & $2.238-16.253$ \\
\hline Bulky disease & 0.018 & 2.280 & $1.150-4.522$ & 0.003 & 3.344 & $1.506-7.424$ \\
\hline
\end{tabular}

$\mathrm{CI}=$ Confidence interval; HRS = Hodgkin and Reed-Sternberg; TAM = tumor-associated macrophages; TLNI = total lymph node involvement; IPS = International Prognostic Score.

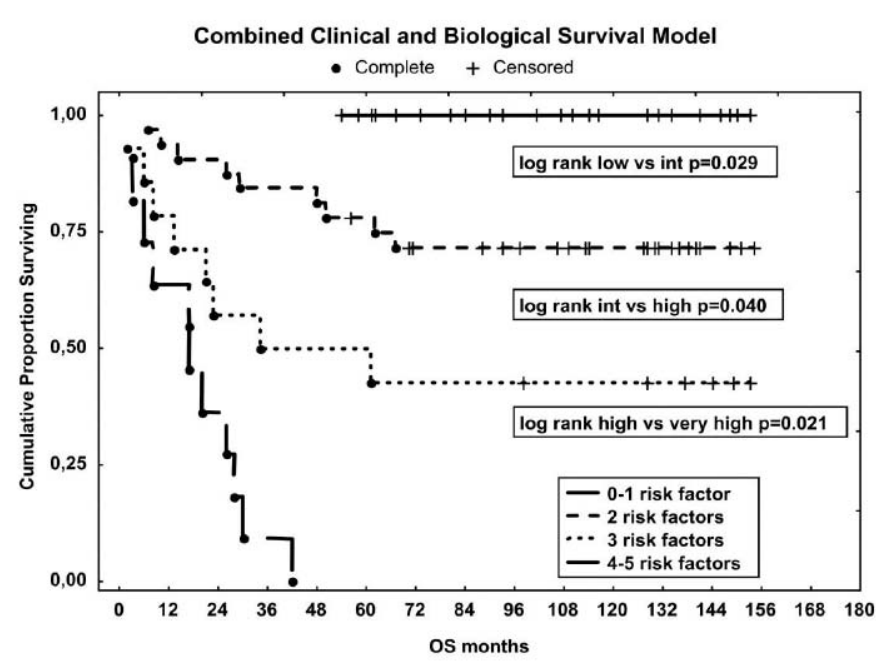

Fig. 2. Survival model. On the basis of the multivariate analysis, prognostic groups were defined using the number of adverse risk factors: Bcl-2, CD68, total lymph node involvement (TLNI), International Prognostic Score (IPS), bulky disease. Low risk, 0-1 risk factors; intermediate, 2; high, 3; very high, 4-5, each with progressively worse 5-year overall survival (OS) $(100,78,45$, and $0 \%$ respectively; $\mathrm{p}<0.001)$.

very high risk. Using these definitions, $33 \%$ of patients in this series were considered low risk, $38 \%$ intermediate, $16 \%$ high, and $13 \%$ very high. Group comparison showed a statistically significant difference in prognosis: low vs. intermediate risk, ( $\log$ rank, $\mathrm{p}=0.029$ ); intermediate vs. high risk (log rank, $\mathrm{p}=0.040)$; high vs. very high risk, (log rank, $\mathrm{p}=0.021)$ (fig. 1$)$. The 5-year OS was progressively worse according to the risk groups: in low risk patients, it was $100 \%$, intermediate $78 \%$, high $45 \%$, and very high $0 \%($ chi square $=42.13, \mathrm{p}<0.001)$ (fig. 2).

\section{Discussion}

The results of our study confirmed 5 independent indicators affecting OS in advanced stage HL. These are overexpression of Bcl-2 (> 50\%); increased number of CD68+ TAM (> 25\%); TLNI; high IPS (>2); and bulky disease. Of these, increased number of CD68+ TAM, IPS > 2, and bulky disease also affected EFS. Combining the identified unfavorable prognostic factors for OS (Bcl-2; CD68; TLNI; IPS; and bulky disease), we designed a prognostic model which stratifies patients into 4 risk groups.
Certain indicators suggest that poorer outcome might depend on a specific molecular mechanism influencing therapy response $[22,23]$. The role of $\mathrm{Bcl}-2$ has been widely debated in the literature without concordant results. Several reports indicated that its overexpression in HRS cells is a predictor of poor outcome [24, 25]. Garcia et al. [11] tried to incorporate biologic variables into the standard clinical prognostic scoring system. Shorter survival was directly connected with Bcl-2 overexpression and other variables such as Bcl-Xl, p53, Bax, MIB1, and the apoptotic index. Also, Sup et al. [26] demonstrated that Bcl-2 but not p53 and p21 was an independent prognostic factor for survival. When clinical parameters (age $\geq 45$ and stage III or IV) were added, the scoring system stratified patients into 3 risk groups (with 0,1 , or 2-3 risk factors) and progressively worse OS and failure-free survival (FFS). More recently, Sanches-Espiridon et al. [27] identified Bcl-2 to be one of the best predictor genes in advanced stage cHL patients. Bcl-2 is integrated into a gene prediction model (including functional pathways: cell cycle, apoptosis, macrophage activation, and interferon regulatory factor 4) which stratified low- and high-risk patients with different FFS rates. However, other reports show that $\mathrm{Bcl}-2$ is not significantly related to outcome $[9,28,29]$. In our study, patients with Bcl-2 overexpression had a worse outcome univariately as well as in a multivariate model adjusted for other relevant risk factors.

Another adverse prognostic factor is the increased number of TAM, described both in solid tumors and B-cell malignancies [30-32]. In addition, several studies revealed a prognostic relevance in HL [33-35]. However, many questions regarding phenotype, chemotaxis, and their influence on treatment resistance in HL remain unanswered. Steidl et al. [13] showed that an elevated number of CD68+ TAM predicts poor outcome in advanced stage patients, while their absence in limited stage disease correlated with total long-term diseasespecific survival. Additionally, Kamper et al. [36] indicated that high expression of the macrophage/monocyte-related antigens CD68 and CD163 was significantly correlated with decreased OS and EFS, with increased CD68 being an independent factor for survival. Gene expression profiling studies also established the significance of TAM in relation to primary treatment failure $[13,37]$. On the other hand, Azambuja et al. [38] could not verify the relationship between the number of CD68+ and CD163+ macrophages with clinical outcome. In our study, we were able to demonstrate that an increased number of TAM had a worse prognosis with respect 
to OS and EFS. Furthermore, the Cox multivariate model revealed that the prognostic impact was independent from other relevant factors for OS and EFS.

TAM are part of the nursing cells in the tumor microenvironment. It is implicated that the unique local microenvironment effect (also referred to as the 'premetastatic niche') might be responsible for homing of circulating HL cells to contiguous lymph nodes early in the course of disease, determining the pattern of metastatic dissemination [39, 40]. Cell line studies showed that clonotypic B cells appears to be responsible for the maintenance and generation of HRS cells [41]. Also, there are findings revealing high levels of circulating clonotypic B cells in stage IV HL as well as in early-stage disease in most patients [41].

In the study by Wasielewski et al. [20] involving 965 nodular sclerosis subtype cHL patients of all stages, the authors found that TLNI with tumor and reactive cells was present in $79 \%$ cases, without influencing survival. In our study, 31 $(36 \%)$ cases with neoplastic and inflammatory TLNI (26 of them with nodular sclerosis) had worse OS both in the univariate and the multivariate model adjusted for other relevant risk factors. Additionally there was a non-significant trend towards lower EFS in this group. The interaction between tumor stem cells and the formation and anatomical organization of the specialized environment which supports them is still under investigation [42]. Whether TLNI represents a part of this process, possibly influencing the clinicobiological variability of the disease, is yet to be clarified.
Our research also confirmed the predictive value of the clinical factors IPS and bulky disease, usually considered important in HL prognosis. We developed a prognostic model for OS, which integrates both clinical and tissue-based variables, in order to stratify advanced stage cHL patients into risk groups. The key parameters for stratification were Bcl-2 positivity in $>50 \%$ of HRS cells, $>25 \%$ CD68+ TAM, neoplastic and inflammatory TLNI, IPS $>2$, and bulky disease. Based on the cumulative score of these risk factors, patients were stratified into 4 groups (low 0-1, intermediate 2, high 3, very high 4-5 risk), each with progressively reduced OS. According to our findings, patients having 2 or more risk factors at the time of the initial diagnosis are at higher risk of a poor outcome. This model, which enables precise risk stratification at presentation, may be used to guide an individual treatment approach, although its predictive value needs to be confirmed in studies with larger numbers of patients.

\section{Acknowledgement}

The study was supported in part by the Ministry of Education and Science of the Republic of Serbia (grant no. 41025).

\section{Disclosure Statement}

The authors indicate no potential conflicts of interest.

\section{References}

1 Diehl V: Hematology. Are macrophages the bad guys in Hodgkin lymphoma? Nat Rev Clin Oncol 2010;7:301-2.

$>2$ Brice P: Managing relapsed and refractory Hodgkin lymphoma. Br J Haematol 2008;141: 3-13.

3 Friedman DL, Constine LS: Late effects of treatment for Hodgkin lymphoma. J Natl Compr Canc Netw 2006;4:249-57.

$\checkmark 4$ Fuchs M, Diehl V, Re D: Current strategies and new approaches in the treatment of Hodgkin's lymphoma. Pathobiology 2006;73:126-40.

$\checkmark 5$ Zender T, Wiedenmann S, Wolf J: Prognostic factors in Hodgkin's lymphoma. Ann Oncol 2002;13: $67-74$.

6 Hasenclever D, Diehl V: A prognostic score for advanced Hodgkin's disease. N Engl J Med 1998;339: 1506-14.

7 Lister TA, Crowther D, Sutcliffe SB, Glatstein E, Canellos GP, Young RC, Rosenberg SA, Coltman CA, Tubiana M: Report of a committee convened to discuss the evaluation and staging of patients with Hodgkin's disease: Cotswold meeting. J Clin Oncol 1989;7:1630-6.

8 Hutchings M, Loft A, Hansen M, Pedersen LM, Buhl T, Jurlander J, Buus S, Keiding S, D'Amore F, Boesen AM, Berthelsen AK, Specht L: FDG-PET after two cycles of chemotherapy predicts treatment failure and progression-free survival in Hodgkin lymphoma. Blood 2006;107:52-9.
9 Montalban C, Garcia JF, Abraira V, GonzalesCamacho L, Morente MM, Bello JL, Conde E, Cruz MA, Garcia-Sanz R, Garcia-Larana J, Grande C, Llanos M, Martinez R, Flores E, Mendez M, Ponderos C, Rayon C, SanchezGodoy P, Zamora J, Piris MA: Influence of biologic markers on the outcome of Hodgkin's lymphoma: a study by the Spanish Hodgkin's Lymphoma Study Group. J Clin Oncol 2004;22: 1664-73.

10 Von Wasielewski R, Georgii A, Fischer R: Clinical impact of grading the nodular sclerosing Hodgkin's disease under modern therapy of the German Hodgkin Study Group. Leuk Lymphoma 1998;29: $0-3$.

11 Garcia JF, Camacho FI, Morente M, Fraga M, Montalban C, Alvaro T, Bellas C, Castano A, Diez A, Flores T, Martin C, Martinez MA, Mazorra F, Menarguez J, Mestre MJ, Mollejo M, Saez AI, Sanchez L, Piris MA: Hodgkin and ReedSternberg cells harbor alterations in the major tumor suppressor pathways and cell-cycle checkpoints. Analysis using tissue microarrays. Blood 2003;101:681-9.

12 Kelley TW, Pohlman B, Elson P, Hsi ED: The ratio of FOXP3+ regulatory $\mathrm{T}$ cells to granzyme $\mathrm{B}+\mathrm{cy}-$ totoxic $\mathrm{T} / \mathrm{NK}$ cells predicts prognosis in classical Hodgkin lymphoma and is independent of bcl-2 and MAL expression. Am J Clin Pathol 2007; 128:958-65.
3 Steidl C, Lee T, Shah SP, Farinha P, Han G, Nayar T, Delaney A, Jones SJ, Iqbal J, Weisenburger DD, Bast MA, Rosenwald A, MullerHermelink HK, Rimsza LM, Campo E, Delabie J, Braziel RM, Cook JR, Tubbs RR, Jaffe ES, Lens G, Connors JM, Staudt LM, Chan WC, Gascoyne RD: Tumor-associated macrophages and survival in classic Hodgkin's lymphoma. N Engl J Med 2010;362:875-85.

14 Rautert R, Schinkothe T, Franklin J, Weinhrauch M, Boll B, Pogge E, Bredenfeld H, Engert A, Diehl V, Re D: Elevated pretreatment interleukin-10 serum level is an International Prognostic Score (IPS)-independent risk factor for early treatment failure in advanced stage Hodgkin lymphoma. Leuk Lymphoma 2008;49:2091-8.

15 Niens M, Visser L, Nolte IM, van der Steege G, Diepstra A, Cordano P, Jarret RF, Te Meerman GJ, Poppema S, van den Berg A: Serum chemokine levels in Hodgkin lymphoma patients: highly increased levels of CCL17 and CCL22. Br J Haematol 2008;140: 527-36.

16 Horning JS: Risk, cure and complications in advanced Hodgkin disease. Hematology Am Soc Hematol Educ Program 2007;197-203.

17 Swerdlow SH, Campo E, Harris NL, Jaffe ES, Pileri SA, Stein H, Thiele J, Vardiman JW: WHO Classification of Tumors of Hematopoietic and Lymphoid Tissues, 4th ed. Lyon, International Agency for Research on Cancer, 2008. 
18 Dukers DF, Meijer C, ten Berge RS, Vos W, Ossenkoppele GJ, Oudejans J. High numbers of active caspase 3-positive Reed-Sternberg cells in pretreatment biopsy specimens of patients with Hodgkin's disease predict favorable clinical outcome. Blood 2002;100:36-42.

19 Rassidakis GZ, Medeiros LJ, McDonell TJ, Viviani S, Bonfante V, Nadali G, Vassilakopoulos TP, Giardini R, Chilosi M, Kittas C, Gianni AM, Bonadonna G, Pizzolo G, Pangalis GA, Cabanillas F, Sarris AH: Bax expression in Hodgkin and ReedSternberg cells of Hodgkin's disease. Correlation with clinical outcome. Clin Cancer Res 2002;8: 488-93.

20 Von Wasielewski S, Franklin J, Fischer R, Hubner K, Hansmann ML, Diehl V, Georgii A, von Wasielewski R: Nodular sclerosing Hodgkin's disease: new grading predicts prognosis in intermediate and advanced stages. Blood 2003;101:4063-9.

21 Specht L: Tumour burden as the main indicator of prognosis in Hodgkin's disease. Eur J Cancer 1992, 28A:1982-5.

22 Axdorph U, Sjoberg J, Grimfors G, Landgren O, Porwit-MacDonald A, Bjorkholm M: Biological markers may add to prediction of outcome achieved by the international prognostic score in Hodgkin's disease. Ann Oncol 2000;11:1405-11.

23 Devilard E, Bertucci F, Trempat P, Bouabdallah R, Loroid B, Giaconia A, Brousset P, Granjeaud S, Nguyen C, Birnbaum D, Birg F, Houlgatte R, Xerri L: Gene expression profiling defines molecular subtypes of classical Hodgkin's disease. Oncogene 2002;21:3095-02.

-24 Rassidakis GZ, Medeiros LJ, Vassilakopoulos TP, Viviani S, Bonfante V, Nadali G, Herling M, Angelopoulou MK, Giardiani R, Chilosi M, Kittas C, McDonnell TJ, Bonadonna G, Gianni AM, Pizzolo G, Pangalis GA, Cabanillas F, Sarris AH: Bcl-2 expression in Hodgkin and Reed-Sternberg cells of classical Hodgkin disease predicts a poorer prognosis in patients treated with ABVD or equivalent regimens. Blood 2002;100:3935-41.

-25 Canioni D, Deau-Fischer B, Taupin P, Ribrag V, Delarue R, Bosq J, Rubio MT, Roux D, Vasiliu V, Varet B, Brousse N, Hermine O: Prognostic significance of new immunohistochemical markers in refractory classical Hodgkin lymphoma: a study of 59 cases. PLoS One 2009;4:e6341.

-26 Sup SJ, Alemany CA, Pohlman B, Elson P, Malhi S, Thakkar S, Steinle R, His ED: Expression of Bcl-2 in classical Hodgkin's lymphoma: an independent predictor of poor outcome. J Clin Oncol 2005;23:3773-9.

27 Sanchez-Espiridion B, Montalban C, Lopez A, Menarguez J, Sabín P, Ruiz-Marcellan C, RuizMarcellan C, Lopez A, Ramos R, Rodriguez J, Canovas A, Camarero C, Canales M, Alves J, Arranz R, Acevedo A, Salar A, Serrano S, Bas A, Moraleda JM, Sanchez-Godoy P, Burgos F, Rayon C, Fresno MF, Larana JG, Garcia-Cosio M, Santonja C, Lopez JL, Llanos M, Mollejo M, Gonzales-Carrero J, Marin A, Forteza J, GarciaSanz R, Tomas JF, Morente MM, Piris MA, Garcia JF: A molecular risk score based on 4 functional pathways for advanced classical Hodgkin lymphoma. Blood 2010;116:e12-e17.

28 Morente MM, Piris MA, Abraira V, Acevedo A, Aguilera B, Bellas C, Fraga M, Garcia-DelMoral R, Gomez-Marcos F, Menargues J, Oliva H, Sanchez-Beato M, Montalban C: Adverse clinical outcome in Hodgkin's disease is associated with loss of retinoblastoma protein expression, high Ki67 proliferation index, and absence of EpsteinBarr virus-latent membrane protein 1 expression. Blood 1997;90:2429-36.

29 Spector N, Milito CB, Biasoli I, Luiz RR, Pulcheri W, Morais JC: The prognostic value of the expression of Bcl-2, p53 and LMP-1 in patients with Hodgkin's lymphoma. Leuk Lymphoma 2005;46:1301-6.

30 Qian BZ, Pollard JW: Macrophage diversity enhances tumor progression and metastasis. Cell 2010;141:39-51.

31 Farinha P, Masoudi H, Skinnider BF, Shumansky K, Spinelli JJ, Gill K, Klasa R, Voss N, Connors JM, Gascoyne RD: Analysis of multiple biomarkers shows that lymphoma-associated macrophage (LAM) content is an independent predictor of survival in follicular lymphoma (FL). Blood 2005;106:2169-74.

32 Burger JA, Ghia P, Rosenwald A, CaligarisCapio F. The microenvoirement in mature B-cell malignancies: a target for new treatment strategies. Blood 2009;114:3367-75.

33 Tzankov A, Matter MS, Dimhofer S: Refined prognostic role of CD68 positive tumor macrophages in the context of the cellular micromilieu of classical Hodgkin lymphoma. Pathobiology 2010;77:301-8.
34 Jakovic LR, Mihaljevic BS, Perunicic Jovanovic MD, Bogdanovic AD, Andjelic BM, Bumbasirevic VZ: The prognostic relevance of tumor associated macrophages in advanced stage classical Hodgkin lymphoma. Leuk Lymphoma 2011;52:1913-9.

35 Yoon DH, Koh YW, Kang HJ, Kim S, Park CS, Lee SW, Suh C, Huh J: CD68 and CD163 as prognostic factors for Korean patients with Hodgkin lymphoma. Eur J Haematol 2012;88:292-305.

36 Kamper P, Bendix K, Hamilton-Dutoit S, Honore B, Nyengaard JR, d'Amore F: Tumorinfiltrating macrophages correlate with adverse prognosis and Epstein-Barr virus status in classical Hodgkin's lymphoma. Haematologica 2011;96:26976.

37 Sanchez-Aguilera A, Montalban C, de la Cueva P, Sanchez-Verde L, Morente MM, Garcia-Cosio M, Garcia-Larana J, Bellas C, Provencio M, Romagosa V, de Sevilla AF, Menarguez J, Sabin P, Mestre MJ, Mendez M, Fresno MF, Nicolas C, Piris MA, Garcia JF: Tumor microenvironment and mitotic checkpoint are key factors in the outcome of classic Hodgkin lymphoma. Blood 2006; 108:662-8.

38 Azambuja D, Natkunam Y, Biasoli I, Lossos IS, Anderson MW, Morais JC, Spector N: Lack of association of tumor-associated macrophages with clinical outcome in patients with classical Hodgkin's lymphoma. Ann Oncol 2012;23:736-42.

39 Kaplan RN, Rafii S, Lyden D: Preparing the 'soil': the premetastatic niche. Cancer Res 2006;66: 11089-93.

40 Kaplan RN, Riba RD, Zacharoulis S, Bramley AH, Vincent L, Costa C, MacDonald DD, Jin DK, Shido K, Kerns SA, Zhu Z, Hicklin D, Wu Y, Port JL, Altorki N, Port ER, Ruggero D, Schmelkov SV, Jensen KK, Rafii S, Lyden D: VEGFR1-positive haematopoietic bone marrow progenitors initiate the pre-metastatic niche. Nature 2005;438:820-7.

41 Jones RJ, Gocke CD, Kasamon YL, Miller CB, Perkins B, Barber JP, Vala MS, Gerber JM, Gellert LL, Siedner M, Lemas MV, Brennan S, Ambinder RF, Matsui W: Circulating clonotypic B cells in classic Hodgkin lymphoma. Blood 2009; 113:5920-6.

42 Lorusso G, Rüegg C: The tumor microenvironment and its contribution to tumor evolution toward metastasis. Histochem Cell Biol 2008;130: 1091-103. 